Uniwersytet Mikołaja Kopernika w Toruniu

Wydziat Nauk Ekonomicznych i Zarządzania

Stanistaw Grochmal

\title{
KULTURA ORGANIZACYJNA PRZEDSIĘBIORSTW EKONOMII KOMUNII JAKO DETERMINANTA JEJ WYMIARU SPOEECZNEGO
}

Z a rys treści. Ekonomia komunii zaproponowana w 1991 roku przez Chiarę Lubich (1920-2008), założycielkę i ówczesną prezydent Ruchu Focolari, jest przedmiotem licznych opracowań naukowych oraz analiz praktycznej jej realizacji przez naukowców różnych dyscyplin w wymiarze ogólnoświatowym. Przedsiębiorstwa realizujące tę ideę w liczbie blisko 800, funkcjonują w wielu krajach na wszystkich kontynentach. Przedmiotem badań jest zarówno doktryna ekonomii komunii i jej znaczenie ekonomiczne, jak też jej wpływ na zmiany kultury organizacyjnej w przedsiębiorstwach oraz relacje w wymiarze społecznym, antropologicznym, kulturowym, a także duchowym.

W artykule zaprezentowano ideę ekonomii komunii i jej realizację w praktyce. Postawiono tezę o społecznym wymiarze ekonomii komunii i jej związku z ekonomią społeczną. Przedstawione zasady realizowane w przedsiębiorstwach ekonomii komunii jako elementy nowej kultury organizacyjnej stanowią argument za udowodnieniem postawionej tezy.

S łow a kluc z ow e : ekonomia komunii, kultura organizacyjna, klimat organizacyjny, ekonomia społeczna.

\section{WPROWADZENIE}

Inspiracją projektu ekonomii komunii było doświadczenie setek tysięcy członków Ruchu Focolari, w którym od ponad 50 lat praktykowane jest radykalne życie według Ewangelii we wszystkich aspektach, także ekonomicznym 
i społecznym (Lubich, 2007). Ruch ten powstał w 1943 roku we Włoszech i po blisko 70 latach jest obecny w ponad 190 krajach wszystkich kontynentów, licząc obecnie kilka milionów członków. Większość członków stanowią katolicy, są jednak w Ruchu obecni także członkowie innych kościołów i religii, a także osoby nie mające konkretnego odniesienia religijnego, ale ceniące wartości uniwersalne: pokój, miłość, jedność, solidarność, prawa człowieka.

Specyficznym celem Ruchu jest dążenie do powszechnego braterstwa, do jedności pomiędzy wszystkimi ludźmi. Realizowana przez członków Ruchu w praktyce komunia dóbr materialnych i duchowych na poziomie osobowym, wspólnotowym i instytucjonalnym kształtowała ich ku widzeniu potrzeb drugiego człowieka i dzieleniu się z nim posiadanymi dobrami, kształtując kulturę dawania zamiast kultury posiadania.

Chiara Lubich, odwiedzając w roku 1991 wspólnoty Ruchu w Brazylii, poruszona ogromnie zróżnicowanym poziomem życia bogatych mieszkańców Sao Paolo i biedaków żyjących w skrajnej nędzy w otaczających miasto barakach „favelas”, a także pod wpływem właśnie wydanej encykliki Jana Pawła II Centesimus annus, zaproponowała podjęcie inicjatyw, mających na celu ograniczenie i docelowo zminimalizowanie niedostatku wśród tych najbiedniejszych. Zaapelowała do członków Ruchu Focolari, aby podjęli inicjatywy tworzenia lub przekształcania przedsiębiorstw produkcyjnych i usługowych, których właściciele przekazywaliby w wolności swojej decyzji 1/3 zysków dla zaspokojenia podstawowych środków do godnego życia osób żyjących w niedostatku (Lubich, 2001). Pozostała część zysków przeznaczona byłaby na rozwój danego przedsiębiorstwa oraz na formację ludzi, chcących realizować i rozwijać ten projekt, zwany ekonomią komunii (EK).

Wieloletnie doświadczenia członków Ruchu utwierdzają w przekonaniu, że najczęściej niedostatek materialny pojawia się tam, gdzie nie funkcjonują lub funkcjonują źle relacje międzyludzkie w różnych aspektach (niesprawiedliwy podział dóbr, wyzysk pracownika, nieprawidłowe odniesienia do pracy, niesumienność, nieuczciwość). Lubich wraz z propozycją podziału zysku przedstawiła nowe zasady zarządzania przedsiębiorstwem oraz działania na rynku w duchu ekonomii komunii.

Ekonomia komunii ma szczególnie duże znaczenie społeczne, wprowadza do współczesnej ekonomii pojęcia do tej pory dalekie od ekonomii rynku, ukazuje inne niż dotychczas możliwości, cele i efekty działalności ekonomicznej. Te właśnie cechy charakterystyczne ekonomii komunii oraz jej związek z ekonomią społeczną będą tematem dalszych rozważań. Sformułowane zasady zarządzania przedsiębiorstwami ekonomii komunii stanowią nowe elementy kultury organizacyjnej tych przedsiębiorstw. 


\section{REALIZACJA I CECHY CHARAKTERYSTYCZNE PROJEKTU EKONOMII KOMUNII}

Projekt ekonomii komunii spotkał się z szybką i bardzo pozytywną odpowiedzią wspólnot Ruchu w całym świecie' ${ }^{1}$. Po 20 latach istnieje ponad 790 przedsiębiorstw działających w duchu EK (najwięcej we Włoszech, w Europie Zachodniej oraz w Ameryce Południowej). Zyski przekazywane w pierwszych latach przez firmy EK były na poziomie kilku tysięcy euro rocznie, w r. 2009 wyniosły ok. $1.5 \mathrm{mln} €$ (Andringa, 2008).

Podział zysku i bezpośrednia pomoc finansowa w formie bezinteresownego daru jest nowością wprowadzoną na płaszczyznę ekonomii, przy czym beneficjenci tej pomocy są uważani za partnerów przedsiębiorstwa, istotnych uczestników projektu EK. Nie ma tu filantropijnej pompatyczności, czy upokarzania zasiłkiem socjalnym, ale współudział, gdzie każdy daje i otrzymuje z jednakową godnością. Relacje z potrzebującymi nie są zatem asymetryczne, jak w typowych inicjatywach charytatywnych i filantropijnych, ale opierają się na wzajemności, stanowiącej podstawę specyficznie rozumianej wymiany dóbr.

Ta istotna i ważna pomoc jest jednak tylko jednym z wielu aspektów EK, jakby „wierzchołkiem góry lodowej”. Jest to najbardziej widoczna i dla niektórych obserwatorów najbardziej spektakularna nowość EK. W istocie EK jest czymś więcej, jest przede wszystkim postawieniem osoby ludzkiej w centrum wszystkich relacji zarówno wewnątrz, jak i na zewnątrz przedsiębiorstwa. Wyraża się nie tylko w uznaniu godności i wartości osób potrzebujących, ale także w pełnym dowartościowaniu kapitału ludzkiego w przedsiębiorstwie. Taka postawa wymaga zmiany kulturowej tak przedsiębiorcy, jak i pracownika, a również innych interesariuszy firmy łącznie $\mathrm{z}$ beneficjentami podziału zysku. Zmiana ta generuje nowe relacje międzyludzkie: przedsiębiorca widzi potrzebę aktywnego uczestniczenia pracowników w podejmowaniu decyzji i traktowania ich jako współodpowiedzialnych w osiąganiu celów przedsiębiorstwa; wzrasta świadomość potrzeby dobrego zarządzania komunikacją w przedsiębiorstwie; podnosi się poziom ogólnej jakości oraz stałej uwagi i troski o klienta.

Relacje międzyludzkie w przedsiębiorstwach EK są owocem wzajemnego zaufania, klimatu wspólnoty, realizującej się poprzez współpracę. W praktyce przekłada się to na kreowanie takiego klimatu organizacyjnego wewnątrz firmy, aby każdy pracownik znalazł odpowiednie warunki do wykonywania jak najlepiej własnych zadań oraz do budowania braterskich relacji z innymi współpracownikami.

1 W ciągu pierwszych dwóch lat realizacji projektu powstało ok. 350 przedsiębiorstw EK. 
Firmy EK charakteryzują także dążenia do dobrych relacji z zewnętrznymi interesariuszami przedsiębiorstwa: klientami, dostawcami, konkurentami, władzami i urzędami, a także autentyczna troska o rozwój wspólnot lokalnych oraz środowisko naturalne.

Koncepcja EK jest realizowana na dwóch poziomach: osobowym, gdyż zasady EK oddziałują na postawę moralną przedsiębiorcy i stają się następnie czynnikiem inspirującym kulturę organizacyjną z bardzo silnym wpływem na klimat organizacyjny w firmie, oraz strukturalnym, następującym zwykle po tym pierwszym, gdy dochodzi do przemian organizacyjnych w przedsiębiorstwie na skutek realizacji wartości proponowanych przez EK oraz gdy inne podmioty gospodarcze widzą i akceptują w firmach EK elementy nowej kultury organizacyjnej, prowadzącej do społeczeństwa bardziej sprawiedliwego.

Część zysków firmy EK przeznaczają na rozwój idei oraz formację osób chcących realizować projekt ekonomii komunii. Są to działania istotne, gdyż bez odpowiednio uformowanych osób nie nastąpi rozpowszechnianie kultury dawania, a bez niej nie byłaby możliwa realizacja ekonomii komunii. Organizowane są spotkania na poziomie lokalnym, międzynarodowe kongresy naukowe oraz szkoły dla przedsiębiorców już uczestniczących w projekcie i potencjalnych jego uczestników. Szczególnie pozytywnie przyjmowana jest idea EK przez osoby młode, studentów różnych kierunków i naukowców (Specht, 2008), czego dowodem jest zrealizowanie w różnych krajach kilkuset prac dyplomowych oraz kilkunastu doktoratów dotyczących ekonomii komunii².

Celem EK nie jest stworzenie jakiegoś uniwersalnego modelu ekonomicznego, czy realizowanie systemu produkcyjnego poza ekonomią rynkową. Jest to natomiast pewna propozycja dla tych, którzy świadomi wartości społecznych zechcą wprowadzić je do ekonomii, z perspektywą, w której rozwój przedsiębiorstwa, dobrobyt pracowników oraz eliminacja ubóstwa w społeczeństwie są de facto jednym, wspólnym celem. Ekonomia komunii proponuje przeniesienie relacji takich, jak w rodzinie naturalnej, najpierw na rodzinę duchową, związaną wyznawaniem tych samych wartości, żyjącą tą samą duchowością wspólnotową, aby docelowo ogarnąc całą rodzinę ludzką.

Jednak z drugiej strony EK krytykuje logikę ekonomii rynkowej nastawionej na maksymalizację zysku, gdyż zysk to tylko jeden z aspektów działalności ekonomicznej i nie można pomijać takich jej wymiarów, jak dar, solidarność, wzajemność, piękno, bezinteresowność, a także duchowość i komunia, które stają się nowymi wyrazami w słowniku współczesnej ekonomii (por. Bruni, 2003).

2 Zestawienie prac naukowych z zakresu ekonomii komunii można znaleźć w: http://www. ecodicom.net/tesi.php. 
Ekonomia komunii przedstawia pewne wyzwanie wobec dychotomicznego modelu państwo-rynek, bowiem nie liczy na efektywne działanie państwa w likwidacji biedy, lecz wykorzystuje rynek nie tylko do wytwarzania bogactwa, ale też jako środek do redystrybucji zysku i tym samym równomiernego rozłożenia bogactwa (Zamagni, 2000). W EK nie oddziela się zatem wytworzenia bogactwa od jego rozdziału.

EK wpisuje się w nurt nauki społecznej Kościoła, dotyczący problematyki ekonomii, pracy, rozwoju i sprawiedliwości społecznej, który tak wspaniale rozwinął Jan Paweł II a kontynuuje Benedykt XVI. W encyklice Caritas in Veritate Ojciec Święty wypowiadając się na temat relacji pomiędzy przedsiębiorczością a etyką stwierdza, że przyjmowane dotychczas rozróżnienie między przedsiębiorstwami mającymi na celu zysk, a organizacjami non profit nie jest już w stanie brać w pełni pod uwagę rzeczywistości, ani też skutecznie ukierunkować przyszłości. W ostatnich dziesięcioleciach pojawił się szeroki obszar pośredni między dwoma typami przedsiębiorstw. Ten obszar pośredni Benedykt XVI (2009, n. 46) nazywa ,wielobarwnym światem podmiotów tak zwanej ekonomii obywatelskiej i wspólnotowej”.

Nie chodzi tylko o „trzeci sektor”, ale o nową, obszerną i złożoną rzeczywistość obejmującą własność prywatną i publiczną, która nie wyklucza zysku, ale uważa go za narzędzie do realizacji celów humanistycznych i społecznych" (ibidem).

Kluczowym wyróżnikiem tak rozumianej ekonomii jest traktowanie zysku nie jako środka do bogacenia się i powiększania własnego kapitału, ale jako instrumentu do realizacji celów społecznych. Jest to wyzwanie skierowane przede wszystkim do firm i korporacji generujących zysk, na których opiera się gospodarka rynkowa i wolny rynek. Gospodarka ta wyszła zwycięsko ze współzawodnictwa $\mathrm{z}$ gospodarką komunistyczną i zapewniła światu olbrzymi postęp. Jednakże postęp ten przyniósł ze sobą także wielkie nierówności pomiędzy ludźmi i nędzę w wielu regionach świata. Jeżeli ma nastąpić zmiana istniejącego stanu rzeczy, trzeba inaczej podejść do wytwarzanego w przedsiębiorstwach zysku (Gądecki, 2010).

Znaczenie, jakie naukowcy przypisują ekonomii komunii, jest bardzo duże. Świadczą o tym liczne nagrody i powszechne uznanie dla C. Lubich (m.in. wśród 16 doktoratów honoris causa 4 dotyczą nauk społecznych i ekonomii komunii), a także setki publikacji naukowych, nie tylko z zakresu ekonomii. Warto przytoczyć słowa A. Bieli, promotora pierwszego doktoratu h.c. przyznanego Lubich przez Katolicki Uniwersytet Lubelski w 1996 r., który określił „ekonomię komunii jako fenomen, który w naukach społecznych może być porównywany z 'rewolucją kopernikańską' w naukach przyrodniczych” (Biela, 1996). 


\section{CEL I MISJA PRZEDSIĘBIORSTW EKONOMII KOMUNII}

Ekonomia komunii stawia w centrum systemu ekonomicznego człowieka i jego szczęście a nie wzrost kapitału i zysk. Celem zasadniczym jest funkcjonowanie na rynku w warunkach normalnej gospodarki oraz stworzenie wspólnoty osób, które produkują dobra materialne i świadczą usługi, generując zyski, aby rozwijać firmę, ale też po to, aby przekazywać ich część do wspólnoty z przeznaczeniem dla osób potrzebujących. Udział w zysku nie należy się bowiem tylko tym, którzy działają w przedsiębiorstwie i udzielają swoich talentów i kapitału, ale także tym, którzy są najbardziej potrzebujący, najbiedniejszym.

EK proponuje postawy kierujące się bezinteresownością, solidarnością i szacunkiem dla najbiedniejszych - postawy uważane zwykle za typowe dla organizacji non profit. Sugeruje je również firmom, dla których naturalną rzeczą jest szukanie zysku. Tak więc EK nie tyle proponuje nową formę przedsiębiorstwa, ile alternatywę dla już istniejących. Pragnie przemienić struktury przedsiębiorstw układając wszystkie relacje wewnątrz przedsiębiorstwa i poza nim w świetle stylu życia komunią, ale z zachowaniem autentycznych wartości przedsiębiorstwa i rynku.

Teleologia przedsiębiorstw ekonomii komunii jest zbieżna z wykładnią celu przedsiębiorstwa, prezentowaną przez Jana Pawła II w encyklice Centesimus annus:

Jednakże zysk nie jest jedynym wskaźnikiem dobrego funkcjonowania przedsiębiorstwa. Może się zdarzyć, że mimo poprawnego rachunku ekonomicznego, ludzie, którzy stanowia najcenniejszy majątek przedsiębiorstwa, sa poniżani i obraża się ich godność. Jest to nie tylko moralnie niedopuszczalne, lecz na dhuższa metę musi też negatywnie odbić się na gospodarczej skuteczności przedsiębiorstwa. Celem zaś przedsiębiorstwa nie jest po prostu wytwarzanie zysku, ale samo jego istnienie jako wspólnoty ludzi, którzy na różny sposób dąża do zaspokojenia swych podstawowych potrzeb i stanowia szczególna grupe stużaca catemu społeczeństwu. Zysk nie jest jedynym regulatorem życia przedsiębiorstwa; obok niego należy brać pod uwagę czynniki ludzkie i moralne, które z perspektywy dhuższego czasu okazuja się przynajmniej równie istotne dla życia przedsiębiorstw (Jan Paweł II, 1991, n. 35).

Firmy EK starają się we wszystkich aspektach swojej działalności stawiać w centrum uwagi potrzeby i aspiracje osoby oraz dobro wspólne. Celem 
końcowym tych firm, który wynika z całego dziedzictwa kulturowego i duchowego Ruchu Focolari oraz Nauki Społecznej Kościoła, jest odpowiedź na potrzeby ludzi, przynależących lub związanych z przedsiębiorstwem oraz potrzebujących. Innymi słowy - wg określenia Lubich - celem EK jest postawienie w centrum wszelkich procesów socjoekonomicznych człowieka i relacji międzyludzkich, unikając zachowań przeciwnych miłości ewangelicznej (Lubich, 2001a).

Misją przedsiębiorstw EK jest spełnienie pewnego wektora celów o równoważnych składowych: osiąganie zysku gwarantującego ekonomiczną stabilność, zaspokajanie potrzeb osób żyjących w niedostatku, dawanie świadectwa przyczyniającego się do rozwoju idei i kształtowania postaw zgodnych z projektem EK oraz poszanowanie środowiska naturalnego i wspieranie lokalnej społeczności, przyjmując wspólnotę za podstawową wartość organizacji (Fortunati, 2002). W oparciu o teorię interesariuszy misja przedsiębiorstw EK może być także określana jako dążenie do spełnienia oczekiwań wszystkich interesariuszy przedsiębiorstwa, przy czym należy je rozumieć jako koniunkcję tych oczekiwań (Grochmal, 2010).

Cele te firmy EK osiągają poprzez wysoką etykę działania we wszystkich aspektach działalności oraz znaczną uwagę zwracaną na jakość procesu produkcyjnego i produktów, a nie tylko na ich dystrybucję. Firmy EK nie ograniczają się jedynie do pojedynczych aktów filantropii, ale w ramach przedsiębiorstw tworzą wspólnoty realizujące pomoc dla ubogich w sposób ciągły, stwarzając im konkretne szanse na definitywne wyjście z ubóstwa.

Z tak określonej misji wynikają też pewne cele szczegółowe: wykorzystanie efektów synergii w procesie pracy, budowanie dobrego klimatu organizacyjnego, stosowanie zasad przejrzystości w zarządzaniu firmą, ukazywanie wpływu wartości duchowych w działalności przedsiębiorstwa, stosowanie zasad etyki biznesu (Bruni, 2000).

\section{AKSJOLOGICZNE ASPEKTY SPOŁECZNEGO WYMIARU EKONOMII KOMUNII}

Przedsiębiorstwa EK charakteryzuje mocna kultura organizacyjna, która warunkuje w sposób istotny realizację misji organizacji. Ta kultura jest zasadniczą cechą EK i w sensie aksjologicznym wnosi na płaszczyznę ekonomii nową wartość, jaką jest kultura dawania, przyjmująca za punkt centralny człowieka i relacje międzyludzkie. Przedsiębiorcy działający w ramach EK uważają swoje firmy nie tylko za miejsca realizacji tej nowej kultury, ale także za środki jej rozpowszechniania na rynku i w społeczeństwie. 
Inspiracją tej nowej kultury organizacyjnej były wieloletnie doświadczenia członków Ruchu Focolari, którego duchowość jest w dużym stopniu ukierunkowana na budowanie jedności z wszystkimi ludźmi dobrej woli. Jednoczenie się z drugim, to m.in. rozumienie jego potrzeb i dążenie do ich zaspakajania, widziane i realizowane także w wymiarze społecznym i ekonomicznym. Człowiek oprócz zaspokojenia potrzeb bytowych i socjalnych pragnie, może nawet w znacznie większym stopniu, być dowartościowanym, szanowanym w swojej godności, uznawanym w swoich działaniach, szczególnie tam, gdzie realizuje swoje zaangażowanie społeczne, np. w pracy. Relacje międzyludzkie w środowisku pracy oraz wyznawane przez pracodawców i pracowników systemy wartości przenoszą się także na zewnątrz przedsiębiorstwa, dotyczą bowiem również interesariuszy zewnętrznych.

Współczesne badania rynku wykazują, że klienci częściej kupują produkty tych firm, o których uzyskują wiarygodną informację, że stosowane są w nich mechanizmy tworzenia dobrych relacji interpersonalnych, dowartościowania i szanowania osób (Zamagni, 2003). Realizacja misji przez firmy EK, motywując je m.in. do kierowania się w działalności ekonomicznej etyką i tworzenia podstaw do kultury dawania, stanowi zatem pośrednio znaczący element przewagi konkurencyjnej firmy. Świadomość tej przewagi często staje się elementem wyróżniającym firmy EK na rynku konkurencyjnym, tym bardziej, że ich strategia marketingowa zakłada podkreślanie istotnych elementów etycznych w swoich działaniach zamiast agresywnej kampanii negatywnej prowadzonej wobec konkurentów (Ridolfi, 2008).

Działanie odpowiedzialne lub wg przyjętego kanonu wartości etycznych niesie z sobą ryzyko utraty dobrych efektów ekonomicznych, gdyż konkurenci, nie stosując się do przyjętych standardów etycznych, mogą podejmować inne działania zwiększające zysk.

$\mathrm{Z}$ drugiej strony mocne zaangażowanie się po stronie wartości przynosi bardzo istotną przewagę konkurencyjną. Po pierwsze dochodzi do powstania pewnego rodzaju wspólnoto-wego kapitału ludzkiego o dużej efektywności produkcyjnej. Współdzielenie i rozumienie misji firmy przyczynia się do wzrostu motywacji do pracy, co często staje się ,,swoistym kołem zamachowym rozwoju, mobilizującym wyobraźnię, energię i zdolności profesjonalne" (Parolin i Puangco, 2002, s. 16). Ponadto dowartościowanie jako osoby pracownika, klienta czy dostawcy jest autentycznym narzędziem konkurencyjności (Zamagni, 2003).

Bliskie i dobre relacje pomiędzy pracownikami oraz z interesariuszami zewnętrznymi tworzą kapitał relacyjny, umożliwiający zarządzanie sytuacjami kryzysowymi w firmie, rozwiązywanie konfliktów, przyjmowanie pozytywnej postawy zaangażowania względem firmy, tworzący dobry wizerunek marki, otwierający przedsiębiorstwo na innowacje. 
To wszystko wynika z postawy społecznie odpowiedzialnej każdego „elementu” firmy, jest zatem korzyścią typu „dobrych praktyk” ukierunkowanych nie tyle na rentowność finansową, co na wartość samą w sobie. Ekonomia komunii reprezentuje ewolucyjny wariant społecznej odpowiedzialności przedsiębiorstw (CSR) (Ridolfi, 2008; Grochmal, 2010), gdyż przedsiębiorcy działają społecznie odpowiedzialnie nie dlatego, że to się opłaca (w sensie np. przewagi konkurencyjnej), ale dla samej wartości społecznej odpowiedzialności.

Ekonomia komunii odnosi się przede wszystkim do przedsiębiorstw a nie organizacji pozarządowych, fundacji czy instytucji charytatywnych. Lubich uważa, że przedsiębiorstwo jest miejscem, gdzie poprzez nową kulturę (kulturę dawania) tworzy się wspólnota, więzi społeczne pomiędzy jej członkami, realizuje się społeczne powołanie przedsiębiorstwa, tworzy się kapitał społeczny (Bruni, 2004). Świadomość społecznej roli przedsiębiorstwa przyczynia się do zrozumienia i znaczącego wzrostu odpowiedzialności społecznej.

Przedsiębiorstwo jest dobrem społecznym powierzonym przedsiębiorcy i nie może ograniczać się tylko do własnego rozwoju, ale powinno rozwijać swoją działalność, aby pomagać potrzebującym oraz szerzyć kulturę dawania poprzez formację kulturową. Wynika $\mathrm{z}$ tego pewien styl zarządzania, który wewnętrzne i zewnętrzne relacje stawia na płaszczyźnie współpracy, wzajemnego szacunku i zaufania.

Przeznaczanie części zysku przedsiębiorstw na cele społeczne nie jest czymś nowym w ekonomii. Niektóre firmy komercyjne przeznaczają część swego zysku na finansowania różnych celów o charakterze społecznym. Często jednak czynią to w celu promocji własnej firmy lub marki (tym samym, aby zwiększyć przyszłe zyski).

EK posługuje się natomiast rynkiem, aby osiągnąć (w sposób odmienny niż firmy komercyjne) zysk i równocześnie go rozdzielić. To jest nowość, która odróżnia firmy EK zarówno od etycznej finansjery (filantropii), jak i od organizacji non profit (Zamagni, 1999).

Takie podejście całkowicie zmienia dotychczasowe rozumienie celu przedsiębiorstwa. Według EK przedsiębiorstwo powinno być wspólnotą osób stale uwrażliwioną na relacje, na funkcje (Bruni, 2003a). Wszyscy pozostający w jakichkolwiek relacjach z przedsiębiorstwem powinni wykazywać się aktywnym udziałem w życiu firmy, być głęboko przekonanymi, że pracować znaczy pracować z innymi i pracować dla innych: znaczy robić coś dla kogoś (Jan Paweł II, 1991, n. 31). Zasoby, którymi dysponuje przedsiębiorstwo, produkowane dobra oraz osiągane zyski są ukierunkowane na wzrost produkcyjności dla dobra człowieka i całego społeczeństwa. Istotnym celem EK jest dobro wspólne, rozumiane w sensie społecznym, na które powinna być nakierowana cała działalność ekonomiczna tak, aby przedsiębiorstwo można było uważać za dobro społeczne. 


\section{EKONOMIA KOMUNII A EKONOMIA SPOŁECZNA - ANALOGIE I RÓŻNICE}

Doświadczenia solidarności w ekonomii mają dość bogatą historię, począwszy od tzw. jezuickich redukcji misyjnych w Ameryce Południowej, przez banki pobożne (Monti di Pietà) w europejskich miastach późnego średniowiecza, niektóre doświadczenia ekonomiczne powstałe w łonie kościoła reformowanego (kwakrzy), doświadczenie New Harmony Owena, banki spółdzielcze Raiffeisena, aż po wielki ruch spółdzielczy, również obecnie dobrze rozwinięty w wielu krajach (Bruni, 2001). Te doświadczenia to zaledwie wybrane przykłady potwierdzające dążenia człowieka do stosowania w życiu gospodarczym zasad sprawiedli-wości społecznej. Często źródłem nowych idei ekonomicznych były charyzmaty (religijne lub świeckie). Z charyzmatu jedności Ruchu Focolari wywodzi się ekonomia komunii. Natomiast dla ekonomii społecznej można określić źródła zarówno religijne jak i świeckie, ponadto w różnych krajach i kulturach ta inspiracja jest inna (Wygnański, 2009).

Ekonomia społeczna (ES) określana jest jako myśl ekonomiczna, która wykorzystuje mechanizmy rynkowe nie do robienia indywidualnych interesów, ale do realizacji celów o charakterze społecznym i misyjnym, w oparciu o ideę wzajemności i braterstwa. Traktuje ona rynek jako narzędzie, uznając obowiązujące w nim reguły, ale nie uważa go za cel sam w sobie (Wygnański, 2006).

W ramach ekonomii społecznej można wyróżnić dwa rodzaje doświadczeń. Pierwsze, to działania, które ukierunkowane na wartości i życie dla innych, pozostawiają jednak na uboczu problemy rynku; są to doświadczenia organizacji pozarządowych, charytatywnych, non profit, które działają poza konkurencją rynku i jego prawami. Drugie, to doświadczenia, które pozostają na rynku, stają wobec konkurencji, dążą do korzyści dla udziałowców (także o charakterze społecznym), a nie innych osób „z zewnątrz”.

Z tak sformułowanego pojęcia ekonomii społecznej wynika, że także ekonomia komunii nie jest marginalnym doświadczeniem realizowanym przez poczciwych przedsiębiorców, którzy usiłują wypełnić lukę w dominującej ekonomii kapitalistycznej, ale jest w pełnym znaczeniu tego słowa nową wizją ekonomii. Jest ona nowym spojrzeniem, którego nie można kwalifikować wg typowego dla ekonomii kapitalistycznej podziału na firmy for profit i non profit. Niektórzy ekonomiści przyrównują EK do paradygmatu przedsiębiorstw for project, typowego dla ekonomii społecznej, w którym przedsiębiorcy uczestniczą we wspólnych projektach (Bruni, 2010).

Przedstawiona prezentacja EK upoważnia do postawienia tezy o jej silnym związku z ekonomią społeczną, o wspólnych mechanizmach i elementach 
teleologicznych, pomimo stosowania różnych metod oraz często różniących obie ekonomie inspiracjach.

W ES działania ekonomiczne są traktowane jako „służba” wobec drugiego człowieka, natomiast w EK działanie ekonomiczne jest rozumiane jako „relacja miłości” pozwalająca na wspólną realizację siebie i drugiego. W jednym i w drugim przypadku motywacja działań ekonomicznych oparta jest na etyce wzajemności. W działających współcześnie organizacjach non profit, czy szerzej, trzeciego sektora podstawowa kategoria „wzajemności” pozostaje bardzo blisko pojęcia „komunii”, chociaż nie identyfikuje się z nim w pełni.

Zarówno w ES jak i w EK jest jasno sformułowana misja społeczna: dążenie do eliminacji lub ograniczenia ubóstwa poprzez wykorzystanie przedsiębiorstw działających w gospodarce rynkowej. Przedsiębiorstwa tak ES jak i EK stawiają sobie za cel służyć na rzecz powszechnego braterstwa, „odnawiając” swoje działanie, a bardziej ogólnie, rynku.

Wygnański (2009) wyraża opinię, że zarówno współcześni wyznawcy państwa jak i wyznawcy rynku mają skłonność do ignorowania tego, co jest pośrodku. W publicznej dyskusji brakuje - jego zdaniem - opcji bardziej wspólnotowej. Mało jest w tej dyskusji miejsca dla tych, którzy wierzą, że poza wolnością i równością powinno być miejsce dla solidarności i braterstwa w ich właściwej postaci - tej, która bierze się z wolnego wyboru. Właśnie wspólnotę oraz działania ekonomiczne według idei braterstwa, solidarności i wzajemności proponuje jako wartości zasadnicze i podstawowe założenia ekonomia komunii.

ES zakłada realizację określonych społecznie wartości i preferencji wykorzystując mechanizmy rynku, rozwijając współpracę i solidarność w życiu społecznym, bazując na wzajemności i zaufaniu jako podstawach relacji międzyosobowych. Przyjęcie takich zasad pozwala często przedsiębiorstwom społecznym stać się konkurencyjnymi wobec innych operatorów na rynku.

Zarówno założenia jak i cele ES i EK są w dużym stopniu zbieżne. Różnice występują m.in. w przyjętych metodach. ES dąży do sprawiedliwego podziału dóbr uzyskanych w wyniku działalności gospodarczej nie nastawionej na zysk (non profit), EK proponuje działania komercyjne a osiągnięty zysk przeznacza w części na cele społeczne. Takie zróżnicowanie nie zawsze jest uzasadnione, gdyż z jednej strony organizacje non profit mogą wypracowany zysk przeznaczyć na określone statutowo cele, a $\mathrm{z}$ drugiej strony w projekcie ekonomii komunii mogą uczestniczyć np. spółdzielnie, zgodnie z przyjętym zapisem w ich statucie oraz zależnie od obowiązującego w danym państwie prawa handlowego i podatkowego. Realizacja przyjętych celów społecznych jest także uwarunkowana akceptacją takich zamierzeń przez akcjonariuszy przedsiębiorstwa czy organizacji, posiadających udziały w kapitale lub prawo do decyzji o przeznaczeniu wypracowanych zysków (zarząd firmy lub zgromadzenie udziałowców spółdzielni). 
Warto także postawić pytanie, czym mogą się wzajemnie wspierać ekonomia społeczna i ekonomia komunii. Jednym z zagrożeń ES jest lekceważenie praw rynku i niezbędnej efektywności przedsiębiorstw. Często organizacje non profit nie potrafią reagować na skutki mechanizmów rynkowych, lub nie poddawane kontroli społecznej, bagatelizują ten problem. Może to prowadzić do upadku firmy lub znacznych strat ekonomicznych. ES może skorzystać z doświadczeń EK, gdzie mechanizmy rynkowe są traktowane jak w każdym innym przedsiębiorstwie komercyjnym, a także z doświadczeń, jak uniknąć błędów ekonomii kolektywistycznej i socjalistycznej, której pewne cechy może ES przyjmować.

EK może też ukazać ważną rolę ducha przedsiębiorczości realizowanej dla celów społecznych, zarówno wśród przedsiębiorców, jak i całej wspólnoty. Istotną rolę w rozwoju ES może spełnić rozumienie znaczenia kapitału społecznego, istotnego elementu firm EK.

ES stawia sobie za cel stworzenie szansy osobom dotkniętym ubóstwem na wyjście z biedy, na wyzwolenie z pozycji klienta, przedmiotu filantropii i pomocy socjalnej, pozycji osoby zależnej od pomocy innych - także ze strony organizacji pozarządowych, a więc szansy na samodzielną zdolność zadbania o los swój i swoich najbliższych. Także dla organizacji celem jest wyzwolenie od postawy „jałmużnika" i uzależnienia od preferencji publicznych i prywatnych sponsorów. W tym zakresie EK nie tylko może stać się istotnym, doświadczonym doradcą ES, ale może ją ubogacić integralną wizją człowieka i organizacji, całym „pozaekonomicznym" bogactwem idei ekonomii komunii.

Ekonomia komunii, która $\mathrm{w}$ realizacji postawionych zadań ogranicza się do członków Ruchu Focolari oraz osób z nim związanych, może skorzystać z doświadczeń ES w propagowaniu idei w szerszym wymiarze, w proponowaniu uczestniczenia w projekcie EK wielu przedsiębiorcom dobrej woli.

Należy wyraźnie zaznaczyć, że rozwój idei EK nie byłby możliwy, gdyby jej projekt nie został „zasiany” na dobrze przygotowany grunt wspólnoty Ruchu Focolari. W tej bowiem wspólnocie praktykowanie od wielu lat ewangelicznej miłości bliźniego w wymiarze indywidualnym i społecznym, życie kulturą dawania i szerzenie charyzmatu jedności stworzyło warunki do wcielenia i szybkiego rozwoju idei EK. Duchowość Ruchu Focolari i jej praktykowanie w życiu codziennym dają wielu przedsiębiorcom EK siłę do podejmowania i realizowania tej idei a beneficjentów utwierdzają w przekonaniu o ojcowskiej miłości Boga.

Chrześcijańska myśl społeczna, a w szczególności Katolicka Nauka Społeczna może być znaczącym wsparciem także dla rozwoju ekonomii społecznej, a doświadczenia EK - pomocą w urzeczywistnieniu w przedsiębiorczości haseł takich, jak wzajemność, bezinteresowność, braterstwo, dar. Rozwinięta doktryna EK może też ukierunkować naukowców na nowe problemy ekonomii i polityki społecznej. 


\section{ELEMENTY KULTURY ORGANIZACYJNEJ PRZEDSIĘBIORSTW EKONOMII KOMUNII}

Ekonomia komunii promuje wizję działań ekonomicznych jako integralną promocję człowieka i społeczeństwa, poprzez działania i zachowania inspirowane przez ideę braterstwa. $Z$ racji swoich celów i misji jest uważana za ekonomię prospołeczną, dążącą do poprawienia stosunków międzyludzkich oraz poziomu życia tych najbiedniejszych, często wykluczonych członków rodziny ludzkiej. Wyraża się to poprzez elementy kultury organizacyjnej w zarządzaniu firmą w każdym niemal aspekcie działalności człowieka:

- w aspekcie antropologicznym: dowartościowanie każdej osoby w przedsiębiorstwie, niezależnie od jej funkcji i roli; budowanie szczerych i pełnych szacunku relacji z klientami, dostawcami, administracją publiczną, konkurencją; wychowywanie do otwartości na świat poprzez współpracę przedsiębiorstw z różnych krajów;

- w aspekcie pracy: widzenie pracy w całej jej godności niezależnie od poziomu technologicznego czy organizacyjnego z dążeniem do profesjonalizmu; promowanie kreatywności i kompetencji; kształtowanie kultury pracy ,, dla” i pracy ,z”; troska o zdrowie i bezpieczeństwo pracowników oraz produkty wysokiej jakości i bezpieczne dla klienta; troska o środowisko i szacunek dla natury;

- w aspekcie ekonomicznym: nieograniczanie się przedsiębiorstw do widzenia tylko własnego rozwoju i zysków, ale nastawienie na tworzenie dóbr, usług i miejsc pracy dla dobra wspólnego; respektowanie zasad efektywności, produkcyjności i równomiernego rozwoju, z otwartością na interwencję Opatrzności;

- w aspekcie kulturowym: pomimo funkcjonowania EK w ramach gospodarki rynkowej nieutożsamianie się z kulturą kapitalizmu, tworzenie i rozwijanie nowej kultury, kultury dawania, przeciwstawnej kulturze posiadania; szanowanie opinii innych, uwzględnianie oczekiwań wszystkich interesariuszy;

- w aspekcie duchowym: widzenie w realizacji rad ewangelicznych źródła własnego ubogacania się, rozwoju duchowego, wzrastania w swoim człowieczeństwie, właściwe ustawienie hierarchii spraw duchowych i materialnych.

Wymienione elementy kultury organizacyjnej generują nowy obraz przedsiębiorcy, a także pracownika. Świadczą też o nowym spojrzeniu na metody i kryteria zarządzania przedsiębiorstwem ekonomii komunii. 
Przedsiębiorca EK stara się stworzyć taki klimat organizacyjny, w którym najlepiej będą wykorzystane i dowartościowane zdolności i możliwości pracowników, popierając kreatywność, postawę odpowiedzialności, pozyskiwanie kompetencji zawodowych, umiejętność budowania relacji interpersonalnych, uczestniczenie i zaangażowanie w określaniu i realizowaniu celów przedsiębiorstwa. Decyzje ryzykowne powinien podejmować z dużym poczuciem odpowiedzialności, uwzględniać ich wpływ na wszystkich interesariuszy przedsiębiorstwa, także ubogich, którzy oczekują na jego wsparcie.

Wymaganie bycia przedsiębiorcą (podejmowanie ryzyka, konieczność innowacji, wolność decyzji, instynkt) pozornie wyklucza pozostawanie w komunii z innymi (umiejętność tracenia własnego zdania, jednoczenia się z innymi). Zatem przedsiębiorca EK powinien posiadać umiejętność tracenia swojego „powołania” przedsiębiorcy, aby następnie odnaleźć je w działaniu dla dobra wspólnego. Powinien także umieć działać w warunkach systematycznej niepewności i nie liczyć tylko na siebie, ale z ufnością powierzać się Opatrzności.

Pracownicy czując się współodpowiedzialnymi za rozwój przedsiębiorstwa zgodny z celami EK i jego otwarciem się na społeczeństwo starają się tworzyć i realizować kulturę przedsiębiorstwa, która maksymalizuje „strategię uwagi na drugiego", pracując ,dla” i ,z” drugim. Praca ,dla” wymaga traktowania odbiorcy produkowanych dóbr (produktów) jako bliźniego, z pełną konsekwencją ewangelicznych odniesień do niego. Taka strategia przyczynia się do większej rentowności firmy, gdyż „uwaga na odbiorcę produktów” generuje wyższą jakość produkcji. Praca ,, dla” umożliwia też przekazanie wartości dodanej, jaką ona stanowi, dla tych, którzy nie uczestniczą bezpośrednio w cyklu produkcyjnym, tj. dla ubogich. Z kolei praca ,, z” uczy solidarności, pracy zespołowej i współdziałania dla dobra wspólnego.

Firmy EK budują dobre, otwarte i profesjonalne relacje z otoczeniem, tworząc w ten sposób kapitał niematerialny, bazujący na wzajemnym szacunku i zaufaniu wobec innych firm oraz wszystkich interesariuszy: klientów, dostawców, beneficjentów podziału zysku, administracji publicznej, społeczności lokalnej oraz osób rozwijających ideę EK.

W sposób lojalny i uczciwy przedsiębiorstwo tworzy relacje z firmami konkurencyjnymi, przedstawiając rzeczywistą wartość swoich produktów i powstrzymując się od negatywnych ocen produktów konkurencyjnych.

Praca jest rozumiana w przedsiębiorstwach EK jako element, poprzez który pracownik nie tylko doskonali się zawodowo, ale wzrasta także duchowo, uczestnicząc w przetwarzaniu i ulepszaniu powierzonego mu świata i tworzeniu dobra wspólnego.

Przedsiębiorstwa EK nie tylko działają zgodnie z prawem, ale starają się także działać na rzecz takich jego modyfikacji, aby nie szkodziło ono dobru 
wspólnemu. Postępują etycznie zarówno wobec instytucji fiskalnych, organów kontroli, związków zawodowych jak i wobec własnych pracowników.

Zasadniczym celem przedsiębiorstwa EK jest utworzenie autentycznej wspólnoty. Strategia uwagi na drugą osobę ukierunkowuje wzajemne relacje osobowe na tworzenie w przedsiębiorstwie zbiorowego kapitału ludzkiego, który jest w stanie znacznie ograniczyć sytuacje kryzysowe w firmie i ich skutki. Przedsiębiorcy promują zarówno pracę zespołową jak i inicjatywę i rozwój indywidualny pracownika. Celem jest stworzenie klimatu przyjaznego i umożliwiającego wzajemny szacunek, zaufanie i solidarność.

Przedsiębiorcy zarządzają firmami tak, jakby były one wspólnym dobrem społecznym a nie ich prywatną własnością. Implikuje to maksymalną troskę o środowisko naturalne, wyrażającą się poprzez wytwarzanie produktów i świadczenie usług bezpiecznych, nieniszczących środowisko, poprzez oszczędzanie energii i zasobów naturalnych, inwestycje odnawialnych źródeł energii czy zagospodarowanie odpadów.

Przedsiębiorcy promują wśród swoich pracowników atmosferę wzajemnej pomocy, wsparcia i szacunku, w której w sposób naturalny i wolny oddaje się do dyspozycji innych swoją wiedzę, umiejętności, doświadczenie zawodowe, kompetencje, wzrastając w swoim rozwoju zawodowym i przyczyniając się do rozwoju przedsiębiorstwa. Stale troszczą się o stworzenie otwartego i szczerego klimatu komunikacji wewnątrz i na zewnątrz firmy, promującego wymianę informacji i doświadczeń na wszystkich poziomach odpowiedzialności. Doceniając znaczenie wartości kulturalnych, jakie może wnieść ekonomia komunii we współczesny świat ekonomii i polityki, utrzymują pomiędzy sobą żywy kontakt oraz wzajemne wsparcie, pomoc i solidarność.

\section{ZAKOŃCZENIE}

Na przestrzeni ostatnich dwóch stuleci kapitalizm osiągnął nadzwyczajne rezultaty ekonomiczne i technologiczne odgrywając ważną rolę $\mathrm{w}$ transformacji społeczeństw. Przegrał jednak na polu braterstwa i solidarności, doprowadzając do przepaści pomiędzy bogatymi i biednymi, tak w wymiarze jednostek, jak państw i społeczeństw. Współczesny kryzys w wielu dziedzinach, będący przede wszystkim kryzysem etycznym, pokazuje w sposób ewidentny, że ekonomia rynku dobiega kresu, wyczerpuje siły do przemian społecznych i cywilizacyjnych. Za zdobycze na polu wolności indywidualnej płacimy ogromną ceną - zniszczeniem środowiska i relacji społecznych.

Przedstawiony w artykule model ekonomii komunii pokazuje poprzez fakty, że można wytwarzać bogactwa, produkować dobra zachowując przy tym 
wzajemne relacje międzyosobowe, a zarazem nie zostawiać w nędzy i ubóstwie tak ekonomicznym, jak i społecznym braci z naszej wielkiej rodziny ludzkiej.

Dzięki ekonomii komunii udało się i udaje to zrobić w ograniczonym wymiarze - kilkuset przedsiębiorstw, kilkuset tysięcy osób, w wielu krajach świata. A co zrobić, aby uzyskać większy stopień sprawiedliwości społecznej, wyeliminować ubóstwo, osiągnąć powszechne braterstwo w skali globalnej?

Wystarczy znaleźć sposób, aby przenieść na poziom instytucjonalny doświadczenia ekonomii komunii, gdyż bez kultury dawania, kultury wzajemności, które są przeciwwagą dla kultury posiadania, kultury kontraktu, nie rozwiążemy wielkich paradoksów społecznych naszej epoki.

Doświadczenie ekonomii komunii nawiązuje do klasycznej tradycji humanistycznej i chrześcijańskiej ekonomii i podejmuje wyzwanie połączenia rynku i życia społecznego, efektywności i solidarności, ekonomii i komunii. Dzisiaj ekonomia stoi przed decydującym wyborem - może spotkać się z duchowością i otworzyć na drugiego, lub zamknąć się w swoich niepokojach, indywidualizmie i egoizmie. Jest to wybór o wielkiej odpowiedzialności, który dotyczy wszystkich.

\section{LITERATURA}

Benedykt XVI (2009), Caritas in Veritate, Libreria Editrice Vaticana, Watykan.

Bruni L. (2000), L'Economia di Comunione, Vita e Pensiero, Milano

Bruni L., Crivelli L. (2004), Per un'economia di comunione; un approccio multidisciplinare, Città Nuova Editrice, Roma.

Jan Paweł II, (1991), Centesimus annus, Libreria Editrice Vaticana, Watykan.

Lubich C. (2007), Charyzmat jedności, Fundacja Mariapoli-Wydawnictwo M, Kraków. Andringa L. (2008), La destinazione degli utili EdC, Economia di Comunione - una cultura nuova, n. 28

Biela A. (1996), Przestanie jedności. Laudacja wygłoszona 19 czerwca 1996 z okazji nadania tytulu doktora honoris causa KUL Chiarze Lubich, Zeszyty Naukowe KUL, 39 (1996), Lublin, s. 195-211.

Bruni L. (2001), L'Economia di Comunione: fatti e idee per un nuovo umanesimo, Congresso Dieci anni di EdC, 7.04.2001, Castelgandolfo.

Bruni L. (2003), L'Economia civile e il principio di gratuità, Nuova Umanita, XXV (2003/2) 146, s. 163-174.

Bruni L. (2003a), Mercato e societa civile: scontro o incontro? Alcune riflessioni dalla prospettiva della "comunione", Nuova Umanita, XXV (2003/3-4) 147-148, s. $407-418$. 
Bruni L. (2004), L'oggi dell'economia di comunione, in Atti del Convegno internazionale „Nuovi orizzonti dell'EdC” 10-12 settembre 2004, Castel Gandolfo.

Bruni L. (2010), Economia civile e di comunione. Quali diversità?, Città Nuova, 1/2010, s. 18.

Fortunati L.V., Baldarelli M.G. (2002), Aspetti etici e sistema informativo nelle aziende dell'economia di comunione: prime proposizioni, [w:] L. Bruni, V. Peligra, Economia come impegno civile, Città Nuova Editrice, Roma.

Gądecki S. (2010), Filozoficzne podstawy gospodarki społecznej, [w]: IV Ogólnopolskie Spotkania Ekonomii Społecznej, Poznań, 2010.

Grochmal S. (2010), Elementy kultury organizacyjnej jako determinanty działań społecznie odpowiedzialnych $w$ przedsiębiorstwach Ekonomii Komunii, IV Ogólnopolska Konferencja Naukowa - Społeczna Odpowiedzialność Organizacji, Uniwersytet Ekonomiczny Wrocław.

Lubich C. (2001), L'Economia di Comunione: verso un agire economico a 'misura di persona', Wykład z okazji otrzymania doktoratu 'honoris causa' w zakresie Ekonomii i handlu, Università Cattolica di Piacenza, 29.01.1999, [w:] Lubich C., L'Economia di Comunione. Storia e profezia, Città Nuova, Roma.

Lubich C. (2001a), L’Economia di Comunione. Storia e profezia, przemówienie wygłoszone w Trydencie 6 czerwca 2001.

Parolin G., Puangco R.V. (2002), Le imprese “cuore” della globalizzazione, [w:] Economia di Comunione - una cultura nuova, Città Nuova editrice, Roma, n. 13.

Ridolfi L. (2008), Dalla CSR alla Economia di Comunione. Il caso del Polo Lionello. Tesi di laurea in economia e gestione aziendale, Università di Bologna.

Specht L. (2008), The economy of communion in freedom project: A Resource for Catholic Business Education, [w]: Business Education at Catholic Universities: The Role of Mission-Driven Catholic Business Education, The University of Notre Dame, Notre Dame, Indiana.

Wygnański J. (2006), Ekonomia społeczna w Polsce - definicje, zastosowania, oczekiwania, watpliwości, http://www.ekonomiaspoleczna.pl/files/ekonomiaspoleczna.pl/ public/Biblioteka/2006.6.pdf. [stan z 15.02.2011]

Wygnański J. (2009), Ekonomia społeczna - sprzeczność czy konieczność, Studio opinii, http://alfaomega.webnode.com/news/jakub\%20wygna $\%$ C $5 \% 84$ ski $\% 3 \mathrm{~A} \% 20$ ekonomia\%20spo $\%$ C5\%82eczna $\% 20 \%$ E2\%80\%93\%20sprzeczno $\%$ C5\%9B\%C4\%87\%20 czy\%20konieczno\%C5\%9B\%C4\%87\%3F/[10.02.2011]

Zamagni S. (1999), Rimboccarsi le maniche, Citta Nuova, ${ }^{\circ} 4$.

Zamagni S. (2000), Economic Reductionism as a Hindrance to the Analysis of Structural Change, [w:] Structural Change and Economic Dynamics, n. 2, s. 197-208.

Zamagni S. (2003), Il simbolo dell'Economia di Comunione, [w:] "Polo Lionello, casa degli imprenditori”, Atti del convegno svolto a Loppiano il 17-18 maggio 2003, Culturano (MI), Lemagraf sas. 


\section{ORGANIZATIONAL CULTURE OF THE ECONOMY OF COMMUNION ENTERPRISES AS THE DETERMINANT OF THE SOCIAL DIMENSION}

Abstract. Economy of communion proposed in 1991 by Chiara Lubich (1920-2008), founder and contemporary president of the Focolare Movement, is the subject of numerous scientific studies and analysis of its practical implementation by the scientists of different disciplines in a global dimension. Enterprises realizing this idea in a number close to 800 , operate in many countries on all continents. The research is both a doctrine of the economy of communion and its economic importance, as well as its impact on organizational culture changes in the enterprises and relations in a social, anthropological, cultural, and spiritual dimension. The idea of economy of communion and its implementation in practice is presented in the article. The thesis on the social dimension of the economy of communion and its relation to the social economy was formulated. The rules implemented in the economy of communion enterprises as elements of a new organizational culture were presented and constitute an argument for proving of the stated thesis.

K e y w o r d s : economy of communion, organizational culture, organizational climate, civil economy 